\title{
Koncepcje wzmocnienia poznawczego. Próba definicji oraz przegląd metod
}

\author{
Artur Tomasz Gunia \\ Zakład Kognitywistyki, Instytut Filozofii \\ Uniwersytet Jagielloński w Krakowie \\ artur.gunia@uj.edu.pl
}

\begin{abstract}
Abstrakt
Koncepcja wzmocnienia poznawczego (ang. cognitive enhancement) odnosi się do wieloaspektowego i interdyscyplinarnego usprawniania władz poznawczych człowieka. Wzmocnienie poznawcze w szczególności dotyczy sposobów rozszerzenia, intensyfikacji i podniesienia zdolności umysłowych człowieka, w tym - procesów poznawczych, emocji czy zmysłów. Ingerencja ta ma dotyczyć jednostek zdrowych, które świadomie decydują się na przełamanie ograniczeń wynikających z natury ich umysłu. Tekst jest syntezą poglądów na temat wzmocnienia poznawczego głównie z perspektywy filozofii transhumanistycznej. Artykuł zawiera różne definicje wzmocnienia poznawczego, opis metod wzmocnienia poznawczego (biotechnologiczne, niefarmakologiczne i informatyczne) oraz wyzwania i wątpliwości w związku z usprawnianiem władz umysłowych człowieka.
\end{abstract}

Keywords: poznanie; wzmocnienie poznawcze; wzmocnienie ludzkie; kognitywistyka; transhumanizm.

\section{Wprowadzenie}

Pytania w filozofii i kosmologii, które od tysiącleci pozostają bez odpowiedzi, dotyczą głównie problemów początku, struktur mikro- i makrokosmosu, meandrów ludzkiej świadomości oraz sensu świata i życia. Być może człowiek nie jest w stanie na nie odpowiedzieć, ponieważ jego dotychczasowa wiedza jest niezadowalająca. A może brak odpowiedzi na podstawowe pytania wynika z niewystarczających możliwości umysłowych człowieka? Posiadamy zbyt słabo rozwinięty umysł, nasze zdolności poznawcze naznaczone są licznymi ograniczeniami, a informacje są gromadzone i przetwarzane na biologicznym nośniku - mózgu - który jest niewystarczająco pojemny i zbyt wolny. Niezależnie od tego, czy przyczyną tego stanu rzeczy jest powód pierwszy, czy dru- 
gi, można się zastanowić, czy impas ten możliwy jest do przezwyciężenia. Człowiek od czasów prehistorycznych poszukiwał sposobów na ulepszenie procesów poznawczych oraz metod umożliwiających zdobycie wiedzy pewnej. Efekty tych rozwiązań były zauważalne jedynie w niewielkim stopniu bądź pozostawały w sferze hipotetycznej. Realna możliwość znacznego ulepszenia zdolności poznawczych człowieka pojawiła się w XX wieku, kiedy część procesów poznawczych mogła zostać oddelegowana na instrumenty technologiczne, w szczególności narzędzia informatyczne. Mimo że rozwiązania te postawały z myślą o uproszczeniu ludzkiej pracy, można stwierdzić, że zaczęły wykazywać znamiona ludzkiej inteligencji. Pojawia się więc pytanie, czy nie wykorzystać technologii tak, by wkroczyła w subtelną sferę ludzkiej umysłowości, a dzięki temu radykalnie usprawniła władze poznawcze człowieka, przesuwając nałożone na nie naturalne bariery?

Koncepcje przekraczania naturalnych barier mocno akcentowane są w filozofii transhumanistycznej. Jej aktualne badania koncentrują się na grupie trzech problemów: superdtugowieczności, superdobrobytu oraz superinteligencji. Ostatni z wymienionych problemów wiąże się z poprawą ludzkiej inteligencji oraz z wytworzeniem sztucznej inteligencji podobnej czlowiekowi. W kontekście superinteligencji rozwijane jest przez transhumanizm zagadnienie wzmocnienia poznawczego (ang. cognitive enhancement), które dotyczy sposobów rozszerzenia, intensyfikacji i wzrostu zdolności umysłowych człowieka, w tym procesów poznawczych, emocji czy zmysłów. Wszelkie działania wokół wzmocnienia poznawczego realizowane są w sposób interdyscyplinarny, zwłaszcza w dziedzinach takich jak neurobiologia, psychologia, medycyna, farmakologia, informatyka, kognitywistyka, ale także znaczące są koncepcje filozoficzne na temat poznania i umysłu (Bostrom i Sandberg 2009; Hildt 2013).

Nadrzędnym celem usprawnienia władz umysłowych jest oczywiście lepsze przystosowanie do ciągle zmieniającego się otoczenia. To jednak wobec wzmocnienia poznawczego jest również oczekiwanie, że dostarczy ono odpowiedzi na fundamentalne pytania o naturę ludzkiego umysłu, jakie zostały postawione $\mathrm{w}$ ramach epistemologii, filozofii umysłu, psychologii poznawczej czy neuronauk. Pomimo ogromnego postępu w medycynie, informatyce, inżynierii materiałowej czy astronomii, to świadomość i procesy mentalne (mimo ogromnych starań, w tym dosyć obszernej wiedzy na temat pracy mózgu) zbadane są w niewielkim stopniu, a w wielu przypadkach przedstawiane koncepcje opierają się na hipotezach, gdyż świadomość nie daje się wyjaśniać w sposób obiektywny i empiryczny. Również przy obecnym stanie wiedzy nie jesteśmy w stanie ani określić, czy świadomość ma swoje ulokowanie jako określony obszar w mózgu, ani założyć, że jest ona wynikiem aktywności wielu ośrodków tworzących sieć (Edelman i Tononi 2000). Próba wkroczenia w tę najsubtelniejszą sferę ludzkiego bytu wymaga od nas sporej ostrożności oraz poczucia ogromnej odpowiedzialności za poszczególne ingerencje. Tym sa- 
mym zagadnienie wzmocnienia poznawczego jest istotne zarówno pod względem rozwiązań technologicznych, jak i towarzyszących mu konsekwencji etycznych czy społecznych.

Celem artykułu jest wprowadzenie czytelnika w świat wzmocnienia poznawczego. Koncentruję się zwłaszcza na przeglądzie dotychczasowych rozwiązań oraz tych, które staną się możliwe w najbliższej przyszłości. Opisywane rozwiązania z dużym prawdopodobieństwem będą oddziaływać na jakość życia zarówno poszczególnych jednostek, jak i całego społeczeństwa. Tekst składa się z trzech części. Celem pierwszej jest próba odpowiedzi na pytanie: dlaczego wzmocnienie poznawcze będzie korzystne dla jednostki i społeczeństwa? Przedstawione analizy dotyczą barier, jakie są nałożone na ludzkie władze poznawcze, oraz możliwości wpływania na naturalne ograniczenia. Następnie przedstawiono syntezę różnych definicji wzmocnienia poznawczego pojawiające się w literaturze przedmiotu. Druga część to syntetyczny opis wielu metod wzmocnienia poznawczego. Wyłaniają się tutaj trzy główne grupy metod: metody biotechnologiczne, związane z wykorzystaniem środków biotechnologicznych (głównie farmakologii oraz genetyki) w celu usprawnienia funkcjonowania mózgu; metody niefarmakologiczne, dotyczące optymalizacji codziennych czynności życiowych w celu wydajniejszego funkcjonowania umysłu oraz metody informatyczne, czyli metody polegające na wykorzystaniu szeroko rozumianych narzędzi informatycznych do symulowania procesów umysłowych człowieka. Z kolei ostania część dotyczy wyzwań, jakie należy podjąć $\mathrm{w}$ związku $\mathrm{z}$ rozwojem technologii aktywnie wpływających na umysł człowieka.

\section{Ograniczenia umysłu i definicje wzmocnienia poznawczego}

Człowiek od zarania dziejów zamierzał usprawniać funkcjonalność ludzkiego ciała i umysłu. Brak odpowiednich narzędzi mu to utrudniał. Jednak współcześnie medykalizacja coraz szerszych aspektów życia oraz globalne rozpowszechnienie technik informatycznych zaczęły przełamywać naturalne bariery. Stąd wielkie oczekiwanie, by technika przyczyniała się do zachowania pełnej funkcjonalności cielesnej oraz do większej wydajności umysłowej człowieka. W związku z tym pojawia się idea wzmocnienia poznawczego.

Koncepcja wzmocnienia poznawczego po raz pierwszy została mocno zaakcentowana w strategicznym raporcie z 2003 roku Converging Technologies for Improving Human Performance zamówionym na potrzeby Narodowej Fundacji Naukowców Stanów Zjednoczonych (U.S. National Science Foundation) oraz Departamentu Handlu Stanów Zjednoczonych (U.S. Department of Commerce). Przedstawiono w nim metody i narzędzia mające usprawnić kondycję ludzkiej egzystencji w XXI wieku. Poprawa warunków bytowych człowieka ma być możliwa poprzez wykorzystanie zaawansowanych technologii oraz wspólny 
wysiłek wielu specjalistów z różnych dziedzin. Kluczowe mają być tak zwane technologie zbieżne (ang. converging technologies), które powinny być synergicznym połączeniem następujących dziedzin: nanotechnologii, biotechnologii, technologii informacyjnych oraz kognitywistyki (Roco i Bainbridge 2003). Podkreśla się, że poprawa ludzkiej egzystencji będzie możliwa poprzez rozszerzenie możliwości poznawczych i usprawnienie sposobów komunikacji.

W celu poznania możliwości ludzkich funkcji poznawczych należy podjąć analizę dotyczącą komunikacji człowieka z maszynami, tworzyć metody szybszego uczenia się i osiągania lepszych efektów kreatywnego myślenia, a ostatecznie stworzyć „mapę” struktur, funkcji i możliwości ludzkiego umysłu ${ }^{22}$ (Horn 2002) w celu ich udoskonalenia. Metody i techniki usprawniania ludzkich władz poznawczych wpisują się w większy projekt wzmocnienia ludzkiego (ang. human enhancement). Wzmocnienie ludzkie dotyczy czasowego bądź ciągłego przekraczania ograniczeń wynikających z niedoskonałości ludzkiego ciała zarówno metodami naturalnymi, jak i sztucznymi. Metody te mają wykorzystywać nowoczesną technologię i medycynę w celu przekształcania, manipulowania i wzmacniania ludzkiej biologii nawet u jednostek nieprzejawiających znamion chorobowych tak, by usprawnić ludzkie ciało oraz przekroczyć fizjologiczne bariery. Zmiany te mają sprzyjać lepszemu samopoczuciu, redukcji popędów i wysubtelnieniu doznań wpływających na ogólny dobrostan (Bostrom i Savulescu 2009).

Jak przekonuje jeden z pomysłodawców wzmocnienia poznawczego, Nick Bostrom (2005), poprawa zdolności poznawczych będzie bardzo korzystna, gdyż obecnie władze poznawcze człowieka pozwalają na ogląd jedynie wycinka rzeczywistości. Poznawcze ograniczenia sprowadzają go do platońskiej jaskini, w której może jedynie teoretyzować na temat „cieni”, czyli tworzyć uproszczone teorie dopasowane do ludzkiego mózgu. Możliwe jest poznawanie świata na wiele różnych sposobów, jednak przez niedoskonałości i bariery ludzkich władz umysłowych wiele $\mathrm{z}$ nich jest dla niego obecnie niedostępna. Bostrom, wraz z innymi czołowymi twórcami transhumanizmu, wymienia ograniczenia natury mentalnej oraz wyznacza sposoby ich przekroczenia:

1. Zasięg ludzkich zmysłów - człowiek posiada zdolność odbierania bodźców ze świata zewnętrznego za pomocą pięciu podstawowych zmysłów: wzroku, słuchu, dotyku, smaku i węchu. Zmysły te mają swoje ograniczenia, są słabo dostrojone, a ich możliwości są nie w pełni wykorzystane. U osób zdrowych i pełnosprawnych głównym zmysłem odbierania świata zewnętrznego jest wzrok. Pomimo że u człowieka jest on wysokiej ostrości, odbierane jest wyłącznie światło widzialne ${ }^{23}$. Pojawia się tutaj pyta-

\footnotetext{
${ }^{22}$ Human Cognome Project to projekt, w którym badacze mają na celu rozszyfrowanie działania ludzkiego mózgu, podobnie jak to się udało w projekcie poznania ludzkiego genomu.

${ }^{23}$ Światło widzialne - część promieniowania elektromagnetycznego, na którą reaguje siatkówka oka człowieka w procesie widzenia. W przybliżeniu w zakresie długości fal 380-780 nm.
} 
nie: czy zmysłów nie można byłoby wysubtelnić tak, by mogły dostarczać człowiekowi więcej informacji o otaczającym go świecie? Również pojawia się chęć doznawania zmysłów aktualnie nam niedostępnych. Dlaczego człowiek nie mógłby posiadać zmysłów echolokacji, orientacji magnetycznej, możliwości odbierania sygnałów radiowych, możliwości widzenia w podczerwieni i ultrafiolecie oraz bardziej wyostrzonych zmysłów smaku i węchu?

2. Wydajność intelektualna - formowanie solidnych i ogólnych sądów filozoficznych i naukowych w wielu wypadkach kończy się niepowodzeniem. Procesy związane z przetwarzaniem bodźców oraz formowaniem na ich podstawie wiedzy wydają się bardzo ograniczone. Wykonanie kilkuczłonowego równania czy wyciągnięcie zadowalających wniosków $\mathrm{z}$ baz danych jest czasochłonne i pośrednie (wymagające dodatkowych zewnętrznych narzędzi). Rozwiązania technologiczne $w$ realizacji tych zagadnień znacząco przewyższają możliwości człowieka. Dlaczego więc nie dokonać integracji ludzi z maszynami? Istnieje więc chęć poprawienia zdolności umysłowych człowieka poprzez zwiększenie pamięci, podniesienie ilorazu inteligencji oraz polepszenie myślenia abstrakcyjnego i logicznego.

3. Nastrój, energia i samokontrola - wiele ludzkich cech osobowości jest genetycznie zdeterminowanych. Wskutek tego szybkość działania, zdolności umysłowe czy odczuwanie zadowolenia są z góry ustalone. Również $\mathrm{w}$ kwestii pragnień nie zawsze mamy duże pole do manewru. Za nasze decyzje odpowiadają czynniki genetyczne. Pomimo wielu prób i wysiłków nie daje się przez to pewnych wyższych celów osiągnąć. Ingerencje genetyczne pozwoliłyby zachować wiele energii, dałyby większe możliwości w kreowaniu swojej osoby i ułatwiłyby samokontrolę (Bostrom 2005; More 2013).

4. Popędy i emocje - człowiek zachował wiele pierwotnych zachowań zapewniających mu niegdyś przeżycie. Ciągle wiele $\mathrm{z}$ tych zachowań jest zdeterminowanych genetycznie do pierwotnego celu jakim było przetrwanie, a nie szczęście. Stąd w człowieku wciąż tak wiele stanów świadomych, emocji i popędów zakodowanych w biochemię mózgu, które w dzisiejszym świecie są niepotrzebne, niekorzystne oraz wpływają depresyjnie na jednostki. Część negatywnych emocji i popędów w dzisiejszym świecie praktycznie się nie przydaje, a wręcz utrudnia funkcjonowanie i oddala człowieka od szczęścia. Dlaczego nie ingerować w emocje i popędy? Wtedy gdy wpływają negatywnie na jednostkę, można byłoby kontrolować ich udział w ludzkim doświadczeniu (Pearce 2004).

5. Nauka i komunikacja - proces nauki jest często długotrwały i bardzo żmudny. W dzisiejszym świecie człowiek dodatkowo zalewany jest mnóstwem informacji, z których nie sposób wybrać te istotne. Może prowa- 
dzić to do przeciążania ośrodków w mózgu odpowiedzialnych za przetwarzanie informacji. Czy nie można byłoby usprawnić procesu nauczania tak, by był bardziej efektywny, a dostęp do wyuczonej wiedzy był szybszy i precyzyjniejszy? Dlaczego nie zasymilować człowieka z zewnętrznymi magazynami pamięci dla lepszego przechowywania i przetwarzania informacji (Kurzweil i Drexler 2013)?

Projekt mający pozwalać na znoszenie ograniczeń poznawczych nałożonych na człowieka nazwano szerokim projektem wzmocnienia poznawczego, który definiować należy jako całokształt działań mających na celu usprawnienie i rozszerzenie podstawowych zdolności umysłu poprzez poprawę i uzupełnienie systemów poznawczych, co obejmuje usprawnienie inteligencji ${ }^{24}$, poprawienie uwagi, wzmocnienie kreatywności, ulepszenie pamięci czy też rozszerzenie spektrum percepcji (Sandberg i Bostrom 2006). Wzmocnienie poznawcze to także interwencje wymagające zabiegów na ludzkim mózgu i mające poprawić ludzką wiedzę poprzez przyspieszenie i ułatwienie jej nabywania, przetwarzania, przechowywania, aplikacji oraz zwiększenie jej zakresu (Hauskeller 2013). Wzmocnienie poznawcze definiowane jest jako zwiększanie funkcji poznawczych względem możliwości zwykłych i średnich. To także oddziaływanie na neuroplastyczność w celu wzbogacenia doświadczeń poznawczych (Racine i Forlini 2010). Teorie wzmocnienia poznawczego rozszerzane są również o usprawnienia takich stanów umysłu, niebędących sensu stricto funkcjami poznawczymi, jak kontrola, emocje, czynniki motywacyjne (Kipke 2013), a także poszerzenie zakresu zmysłów czy przekroczenie poza typowe ludzkie zmysły (Bostrom 2005).

Idea wzmocnienia poznawczego ma opierać się na dobrowolności stosowania. Odnosi się do ulepszania władz umysłowych, a nie zwalczania objawów chorobowych, stąd też istotne jest, by odróżnić wzmocnienie od terapii (leczenia). Wzmocnienie charakteryzują interwencje mające na celu poprawę ludzkiej funkcjonalności, wykraczające poza konieczne zabiegi utrzymujące lub przywracające pożądany stan zdrowia. W odróżnieniu od terapii, wzmocnienie jest skierowane do osób zdrowych, które decydują się na poprawę zdolności poznawczych. Pojawiające się niedoskonałości poznawcze wynikają z naturalnych barier, a nie są objawami chorobowymi wymagającymi interwencji medycznych (Juengst 1998; Forsberg 2013). Niemniej główne kontrowersje wokół wzmocnienia wywołuje fakt, że stosowane w tym celu techniki i metody mogą wywoływać niepożądane skutki uboczne. Wiele ze skutków ubocznych jest na tyle nowych, że nie zostały do tej pory zbadane, zwłaszcza w związku z długoterminowym stosowaniem wspomnianych technik i metod. Obawy dotyczą również możliwości uzależniania się od środków mających

\footnotetext{
${ }^{24}$ Usprawnienie inteligencji obejmuje $\mathrm{z}$ jednej strony znaczne zwiększenie ilorazu inteligencji osiąganego $\mathrm{w}$ testach na inteligencję, $\mathrm{z}$ drugiej odnosi się do szybkości i adekwatności używanej wiedzy w zależności od zaistniałych sytuacji.
} 
wzmacniać poznanie oraz możliwości utraty efektywności w czasie czy przecenienie własnych możliwości (Brukamp 2013).

Skupiając uwagę na metodach i technikach stosowanych w celu wzmocnienia poznawczego, należy przede wszystkim uwzględnić podział ze względu na sposób oddziaływania na ośrodek nerwowy i świadomość, a także podział ze względu na użyte techniki. Metody wzmocnienia poznawczego w kontekście jego oddziaływania można podzielić na metody wzmocnienia inwazyjnego i bezinwazyjnego. Wzmocnienie inwazyjne wpływa na zmiany w strukturach mózgu poprzez bezpośrednią stymulację ośrodka nerwowego. Związane jest to $\mathrm{z}$ implantacją technologii do ciała, może skutkować długotrwałymi i nieodwracalnymi efektami, prowadzić do zmian osobowości, wiązać się z znaczącym ryzykiem skutków ubocznych, jednak działanie metod inwazyjnych jest wyjątkowo skuteczne (Brukamp 2013; Gilbert 2013). Odmienne są nieinwazyjne metody wzmocnienia poznawczego, które nie wymagają bezpośredniej stymulacji oraz nie wpływają bezpośrednio na biochemię mózgu. Metody te funkcjonują w oparciu o plastyczność mózgu i jego zdolność do adaptacji, a także oparte są na naturalnych metodach uczenia się (Clark 2004; Dresler i in. 2013). Podział metod wzmocnienia poznawczego ze względu na użyte techniki obecnie dotyczy następujących grup: biotechnologiczne wzmocnienie poznawcze, niefarmakologiczne wzmocnienie poznawcze oraz informatyczne wzmocnienie poznawcze.

\section{Biotechnologiczne wzmocnienie poznawcze}

Metody biotechnologiczne odnoszą się głównie do stosowania środków neurofarmakologicznych, to jest substancji psychoaktywnych, w celu wzmocnienia poznawczego u osób zdrowych (Franke i Lieb 2013). Środki te głównie przyczyniają się do zmian w biochemii mózgu. Jeśli chodzi o substancje wpływające korzystnie na funkcje układu nerwowego, to w pierwszej kolejności należy odnieść się do substancji naturalnych. Podstawowym źródłem energii dla mózgu jest glukoza, której dostarczanie umożliwia prawidłowe funkcjonowanie mózgu. Znanymi od wieków naturalnymi środkami wpływającymi na władze poznawcze są między innymi: kofeina, teina, guaranina czy mateina - środki te wzmacniają uwagę i redukują uczucie zmęczenia. Z kolei nikotyna wpływa stymulująco na uwagę i koncentrację. Warto wymienić również suplementy zawierające ekstrakt z miłorzębu dwuklapowego (ginkgo biloba), który ogranicza zaburzenia pamięci (Sandberg i Bostrom 2006). Należy jednak pamiętać, że środki naturalne działają krótkotrwale i selektywnie. Uwaga badaczy jest głównie skupiona na środkach neurofarmakologicznych. Wiele z nich zasadniczo stosowana jest do celów terapeutycznych, głównie do zwalczania chorób o podłożu neurologicznym. Jednak ich efekty zostały zaobserwowane u osób zdrowych, znacznie wzmacniając ich funkcje poznawcze. Grupa środków wpływająca na zdolności związane z pamięcią, uwagą, motywacją i krea- 
tywnością to leki nootropowe lub prokognitywne. Docelowo były przeznaczone do przeciwdziałania chorobie Alzheimera, Parkinsona czy jako środek zapobiegawczy zespołowi nadpobudliwości psychoruchowej (ADHD) (Lanni i in. 2008). Mechanizmy działania środków nootropowych są następujące: (1) zwiększenie cyrkulacji krwi do mózgu, (2) dostarczenie komórek regeneracyjnych do neuroprzekaźników, (3) poprawa funkcji neuronów, 4) zapobieganie niedotlenienia mózgu, (5) dostarczenie większej energii do mózgu (Pranav 2013).

Środki o właściwościach pobudzających takie jak Modafinil (docelowo używany $w$ leczeniu narkolepsji, w celu zmniejszenia senności wywołanej pracą zmianową lub $\mathrm{w}$ problemach $\mathrm{z}$ bezdechem sennym) pozwalają na zwiększenie stężenia dopaminy i noradrenaliny w przestrzeni synaptycznej oraz hamują receptory $G A B A^{25}$. Wywołuje to efekt wzmożonej czujności, silnej koncentracji na założonych celach, trwałego wzmocnienia pamięci oraz przyspieszenia procesu uczenia się. Stosowanie Modafinilu nie zmienia świadomości, lek ten również nie ma działania narkotycznego oraz uzależniającego. Środek ten także zapobiega depresjom, które hamują funkcje poznawcze. Badania wykazały, że studenci stosujący Modafinil, przygotowując się do egzaminów, osiągali zdecydowanie lepsze wyniki niż ich koledzy, którzy przygotowywali się do testów $\mathrm{w}$ tradycyjny sposób (Turner i in. 2003). Aktualnie nie ma sprawdzonych badań dokumentujących długotrwałe stosowanie tego środka, jednak sama możliwość osiągania sukcesu intelektualnego poprzez wspomaganie się środkami farmaceutycznymi wywołuje kontrowersje (Dresler i in. 2013). Czy osoby stosujące tego typu doping oszukiwały? Innym popularnym wspomagającym środkiem jest Prozac, lek przeciwdepresyjny powodujący zwiększenie stężenia neuroprzekaźnika serotoniny w przestrzeni międzysynaptycznej. Stosowany głównie w leczeniu bulimii, zespołu napięcia przedmiesiączkowego (PMS), zespołu lęku napadowego i depresji w przebiegu zaburzenia afektywnego dwubiegunowego. Środek wzmacnia uwagę, wyzwala pozytywne emocje, chęć samodoskonalenia i sprawia, że osoba po jego zażyciu ma wrażenie większych możliwości w kreowaniu swojego życia. Efektem jest też poprawa nastroju oraz kontrolowanie emocji, stąd Prozac nazywany jest „lekiem na szczęście”. Stosowanie Prozacu podobnie jak Modafinilu wpływa korzystanie na relacje zawodowe. Dzięki właściwościom przeciwdepresyjnym jest możliwa dłuższa i wzmożona aktywność procesów poznawczych, nawet pod silnym wpływem czynników stresogennych. Długotrwałe stosowanie prowadzi jednak do zaburzeń innych układów (DeGrazia 2000). Wzmacnianie procesów poznawczych wywołują także liczne środki narkotyczne, na przykład amfetamina i jej pochodne. Środki te są silnie pobudzające, wzmacniają przy tym koncentrację, stąd stosowane są jako środki wspo-

\footnotetext{
${ }^{25}$ GABA (kwas gamma-aminomasłowy) - aminokwas, główny neuroprzekaźnik o charakterze hamulcowym w układzie nerwowym; powoduje hiperpolaryzację komórki postsynaptycznej.
} 
magające proces uczenia się. Na uwadze trzeba mieć, że środki te są inwazyjne i mogą wywoływać wiele efektów niepożądanych zarówno w układzie nerwowym, jak i innych układach. Ponadto posiadają właściwości zmieniające stan świadomości oraz są silnie uzależniające (Soetens, D'Hooge i Hueting 1993). Również część środków jest nielegalna $\mathrm{w}$ wielu państwach bądź dostępna jedynie na receptę, co prowadzi do licznych dyskusji, czy farmakologiczne substancje powinny być dostępne dla osób zdrowych chcących usprawnić działanie swoich władz poznawczych (Bublitz 2013).

Projekty wzmocnienia neurofarmakologicznego zmierzają jeszcze dalej. David Pearce (2007; 2014) przedstawia koncepcję projektowania utopijnych leków (ang. utopian designer drugs). Dostarczałyby one przyjemności, redukując przy tym całkowicie odczuwanie bólu. Utopijne leki umożliwiałyby pełną funkcjonalność przez całe życie, wzmacniałyby doznania, redukowałaby popędy lub usprawniały procesy uczenia i myślenia, pozwalałyby na selektywne wymazywanie pamięci, a przy tym nie wywoływałyby skutków ubocznych. Pearce analizując aktualnie dostępne środki wpływające na redukcję cierpienia, zauważa, że wiele $\mathrm{z}$ nich działa wybiórczo, a przy tym doprowadza do wielu innych niepożądanych stanów. Sam co prawda nie przedstawia konkretnych rozwiązań - jaki powinien być skład oraz na jakie ośrodki w układzie nerwowym będą wpływać utopijne leki. Skupia się przede wszystkim na działaniu, jakie powinny wykazywać. Nadrzędnym celem w projektowaniu utopijnych leków powinno być zwalczanie cierpienia zarówno mentalnego i fizycznego, wyleczenie z manii i nieracjonalnych przekonań. Pearce ma nadzieję, że dzięki środkom farmakologicznym możliwe będzie podniesienie poziomu empatii, wysubtelnienie doznań estetycznych, wyostrzenie doznań duchowych oraz nakierowanie na wielotorowe poczucie moralności.

Pearce (2009) jest również propagatorem metod biotechnologicznych, które budzą jeszcze więcej wątpliwości na gruncie etycznym, a mianowicie modyfikacji genetycznych. Badania takie aktualnie wykonuje się na zwierzętach, gdyż efekty są trwałe i przekazywane na kolejne pokolenia. Selekcja poszczególnych genów u myszy sprawiła, że nowe pokolenia stały się bardziej odporne na ból, szybciej nabywały wiedzę, a ich zasoby pamięci stały się wydajniejsze nawet w starszym wieku. Udoskonalenie i przeniesienie inżynierii genetycznej na ludzi sprawiłoby, że przyszłe pokolenia mogłyby posiadać znacznie wydajniejsze zdolności poznawcze pozbawione aktualnych wad. Modyfikacje genetyczne miałyby polegać przede wszystkim na eliminacji genów, które odpowiadają u człowieka za skłonności do stanów depresyjnych, gniewu, agresji, lęków czy też odpowiedzialnych za wysoki próg bólu, a w ich miejsce należałoby wstawiać geny warunkujące wzrost inteligencji, dobre samopoczucie i odporność na stres. Pearce jest przekonany, że pełna wydajność władz poznawczych nie jest osiągana przez człowieka, gdyż kieruje nim zbyt wiele popędów pierwotnych. Cechy, które są zdeterminowane genetycznie, nie przyczyniają się do szczęścia, wyrafinowanych dokonań naukowych czy ra- 
cjonalnego poczucia moralności, lecz służą raczej przetrwaniu w trudnych i zmiennych warunkach, stąd też odpowiadają za egoizm, agresję i lęk. Dzięki rozumowi człowiek ujarzmił nieprzewidywalną naturę i wprowadził w nią racjonalny porządek. Sam jednak nie zdołał się wyzbyć cech zwierzęcych. Niekorzystne cechy być może uległyby złagodzeniu na drodze doboru naturalnego, jednak jest to proces długotrwały i nieprzewidywalny, stąd też rozsądnym rozwiązaniem wydaje się wykorzystanie dokonań genetyki w celu redukcji niepożądanych stanów wpływających negatywnie na struktury poznawcze człowieka.

Ze względu na dużą inwazyjność tych metod oraz trudne do przewidzenia długotrwałe skutki założenia te opierają się głównie na spekulacji. Pearce jest przekonany, że zarówno projektowanie utopijnych leków, jak i inżynieria genetyczna pozwolą na spełnienie założeń jego koncepcji imperatywu hedonistycznego ${ }^{26}$. Przedstawione przykłady biotechnologicznego wzmocnienia poznawczego to tylko wycinek szerokiej dziedziny. Ten rodzaj wzmocnienia głównie rozwijany jest $\mathrm{w}$ celu projektowania coraz to nowszych, wydajniejszych i mniej szkodliwych neurofarmaceutyków. Trzeba mieć na uwadze, że wiele spożywanych środków wpływa na sferę mentalną. Ważne jest, aby wraz z ich stosowaniem śledzić ich możliwości oraz mierzyć wydajność funkcji poznawczych osiąganych przez ich stosowanie. Również na uwadze trzeba mieć potencjalne niepożądane skutki. Czy mimo braku fizycznego uzależnienia oraz nieszkodliwości niektórych leków nootropowych (Turner i in. 2003) nie będą prowadzić do uzależnienia psychicznego lub nie staną się narzędziem biopolityki? Bądź też jeśli człowiek zredukuje pewne pierwotne popędy albo będzie wymazywał selektywnie pamięć, na przykład w celu eliminacji traumatycznych przeżyć, to czy w pewnym sensie i w pewnym zakresie jego zdolności poznawcze nie zostaną ograniczone? Biotechnologiczne rozwiązania to potężne narzędzia, których działanie jest długotrwałe. W przypadku rozwiązań genetycznych efekty wzmocnienia przekazywane będą na kolejne pokolenia.

\section{Niefarmakologiczne wzmocnienie poznawcze}

Kolejną grupą metod wzmocnienia poznawczego są tzw. metody niefarmakologiczne, które nie powodują większych zastrzeżeń etycznych. Ich działanie jest $\mathrm{w}$ większości nieinwazyjne, opiera się na pewnych naturalnych zachowaniach oraz na metodach prewencyjnych. Jednak metody te dla uzyskania efektów wymagają często długotrwałej aplikacji. Nie oznacza to jednak, że metody

\footnotetext{
${ }^{26}$ Imperatyw hedonistyczny to koncepcja moralna zaproponowana przez Davida Pearce’a, uznająca konieczność używania technologii w celu wyeliminowania cierpienia u wszelkich świadomych istot.
} 
te mają niewielki wpływ na efektywność procesów poznawczych, wręcz przeciwnie, efekty tego wzmocnienia są trwałe i często niezbywalne.

Sandberg i Bostrom wymieniają szereg metod nieinwazyjnych oraz nietechnologicznych ${ }^{27}$, które wpływają na procesy poznawcze. Chcąc zagregować metody wzmocnień niefarmakologicznych, można wyróżnić poszczególne grupy:

a) wzmocnienie jako prewencja rozumiana $\mathrm{w}$ kategorii ochrony przed wpływem czynników działających patologicznie na procesy poznawcze oraz jako proces tworzenia środowiska przyjaznego rozwijaniu zdolności umysłowych;

b) wzmocnienie jako optymalizacja podstawowych procesów fizjologicznych poprzez odpowiednią regulację i racjonalizację codziennych czynności życiowych, co przyczyniać ma się do skuteczniejszego rozwijania zdolności poznawczych;

c) techniki mentalne będące zestawem zadań i ćwiczeń, które pobudzają ośrodki poznawcze oraz wpływają na plastyczność mózgu.

Techniką najsilniej oddziałującą na kondycję ludzkiej umysłowości jest edukacja. Poza oczywistym lepszym przystosowaniem do życia społecznego, można w mierzalny sposób sprawdzić jej efektywność. Powołując się na badania Winshipa oraz Korenmana (1997), szacuje się, że każdy rok edukacji pozwala na wzrost ilorazu inteligencji o około 2,7 punktu. Dodatkowo wymiernym efektem powszechnej edukacji społeczeństwa jest zmniejszenie poziomu przestępczości, popadania w choroby czy szybsze bogacenie się społeczeństwa. Ponadto należy zauważyć, że nauka arytmetyki czy języka znacząco wpływa na pamięć, która powoduje wzrost inteligencji skrystalizowanej, związanej z przyswajaniem i nauką, względem inteligencji płynnej (wrodzonej, będącej czynnikiem biologiczno-genetycznym). Sandberg i Bostrom (2006; 2009) zauważają, że bogatsze zdolności poznawcze są osiągane wtedy, gdy bardziej przyjazne i bezpieczne jest środowisko, co wynika z powszechnej i nowoczesnej służby zdrowia, środowiska wolnego od neurotoksyn ${ }^{28}$ czy umiarkowanego klimatu. Większe dokonania umysłowe (mierzone w wyższym ilorazie inteligencji oraz $\mathrm{w}$ dokonaniach naukowych) są silnie skorelowane z czynnikiem geopolitycznym, pozytywnie więc wpływa na dokonania

\footnotetext{
${ }^{27} \mathrm{~W}$ większości są to techniki, w których technologia nie odgrywa nadrzędnego środka do wsparcia procesów poznawczych, jeśli się pojawia pełni rolę narzędzia pomocniczego bądź służącego pomiarom.

${ }^{28}$ Neurotoksyny są substancjami wpływającymi trująco oraz destrukcyjnie na tkanki nerwowe. Pochodzenie neurotoksyn jest zarówno naturalne (sinice, jad żmii, jad skorpiona, bruzdnice, jad kiełbasiany), jak i sztuczne (rtęć, aluminium, ołów, czad, etanol). Przedostawanie się tych substancji do układu nerwowego w dużych ilościach bywa śmiertelne, w mniejszych prowadzi do chorób neurodegeneracyjnych oraz do spowalniania efektywności procesów poznawczych (Schneider i in. 2001).
} 
umysłowe demokratyzacja, nieprowadzenie wojen, polityka państwa opiekuńczego. Efekty prewencyjnych metod są możliwe do pomiaru poprzez analizy statystyczne poszczególnych zjawisk.

„W zdrowym ciele zdrowy duch” - ludowe powiedzenie idealnie potwierdza się w stosunku do koncepcji wzmocnienia poznawczego. Zdrowy tryb życia i racjonalne wpływanie na swoją fizjologię przekłada się na efekty w sferze mentalnej. Nie trzeba zaawansowanych środków neurofarmakologicznych, by wzmocnić uwagę i zwiększyć pamięć. Odpowiednie dostarczanie środków odżywczych, takich jak glukoza, oraz spożywanie co najmniej 3 litrów wody dla lepszego przyswajania elektrolitów ma związek z dostarczeniem do układu nerwowego związków sodu i potasu, które odgrywają istotną rolę w neuroprzekaźnictwie (Fischer 2012). Z kolei wzmocnieniu nastroju sprzyja spożywanie kawy czy słodyczy. Również ograniczanie pewnych składników z codziennego jadłospisu pozwoli osiągać lepsze efekty poznawcze, na przykład ograniczenie spożywania posiłków zawierających tłuszcze nasycone oraz dużą ilość soli, które obniżają poziom koncentracji oraz pogorszają zdolności decyzyjne (Dresler i in. 2013). Oprócz zbalansowanego żywienia istotna jest regularna aktywność fizyczna. Z jednej strony jest bardzo korzystnym czynnikiem zapobiegania chorobom układu krążenia i zachowania zdrowia $\mathrm{w}$ ogóle, z drugiej strony wpływa także na zdolności poznawcze. Wykazano, że trening aerobiku (i innych ćwiczeń opartych na intensywnej wymianie tlenowej) usprawnia uwagę, przyspiesza szybkość przetwarzania ${ }^{29}$, wpływa na funkcje wykonawcze czy też pamięć (Smith. i in. 2010). Wyzwalany podczas ćwiczeń mechanizm to zwiększony przepływ krwi w hipokampie, który wpływa na wymienione funkcje poznawcze. Pozytywny wpływ ma również regularny i optymalny sen (7-8 godzin, w zaciemnionym pomieszczeniu). Oprócz regeneracji i zachowania energii, wzmacnia zwłaszcza pamięć i kreatywność oraz pozwala zachować dłużej uwagę w ciągu dnia. Powyższe metody odnoszą się do podstawowych zachowań fizjologicznych, podczas których należy pamiętać o ich racjonalizacji i optymalizacji (Dresler i in. 2013).

Oprócz powyższych sposobów można rozpatrzyć niefarmakologiczne, nieinwazyjne i nietechnologiczne techniki mające na celu usprawnienie funkcji poznawczych poprzez wspomaganie naturalnych procesów plastyczności mózgu. Od dawna w celu osiągnięcia lepszych wyników w sporcie zawodnicy stosują trening mentalny, który obejmuje różnego rodzaju metody i techniki mające na celu zwiększenie lub też optymalizację umiejętności danej osoby. Konsekwencją takich czynności ma być wzrost osiągnięć w ważnym dla niej obszarze funkcjonowania. Trening mentalny to głównie metody i ćwiczenia psychologiczne, które poprzez systematyczne i długotrwałe oddziaływanie mogą prowadzić do wzrostu kontroli nad zachowaniem i emocjami, do podniesienia poziomu wielu cech poznawczych, takich jak koncentracja (uwaga)

\footnotetext{
${ }^{29}$ Rozumiana jako zdolność do automatycznego wykonywania czynności.
} 
czy odporność na stres (Wilińska 2013). Wykorzystywane techniki to głównie: techniki relaksacyjne, projekcje wizualizacyjne, trening kontroli uwagi. Z kolei do usprawnienia zapamiętywania długich ciągów alfanumerycznych wykorzystuje się mnemotechniki, czyli sposoby zapamiętywania, przechowywania i przypominania sobie informacji. Badania wykazują, że techniki takie jak „pałac pamięci”, gra słów, akronimy czy wizualne mapy pamięci wykorzystują systemy nawigacji przestrzennej w korze mózgu, co sprzyja zapamiętywaniu. Istotną techniką rozwijania procesów poznawczych jest znana od tysiącleci medytacja. Monitorowanie w laboratorium technik medytacyjnych wykazało wzmocnienie wydajności uwagi, wyostrzoną percepcję i czujność, a także większe możliwości przetwarzania wizualno-przestrzennego, pamięci roboczej oraz funkcji wykonawczych. Również regularne rozwiązywanie krzyżówek oraz zagadek logicznych (sudoku, kakuro, nurikabe, obrazków logicznych itp.) przyczynia się do wzrostu poziomu inteligencji, wzmacnia również umiejętności logicznego i abstrakcyjnego myślenia (Sandberg i Bostrom 2006; Dresler $i$ in. 2013).

Badania te wykazują, że podnoszenie wydajności poznawczej nie musi się odbywać przez technologię czy farmakologię, lecz możliwe jest dzięki racjonalizacji procesów życiowych oraz poprzez naturalne techniki. Ludzki umysł jest bardzo elastyczny, co pozwala na stosowanie wielu rozwiązań. Wymaga to jednak odpowiedniej analizy tego, które zachowania i w jaki sposób powinny być przyswajane, gdyż umysł ma również możliwość adaptowania zachowań oraz cech działających negatywnie na władze poznawcze (lenistwo, dekoncentracja, rozbieżność uwagi). Nadrzędnym problemem wzmocnień niefarmakologicznych jest to, że efekty dają się zauważyć dopiero po latach, do tego wymagają systematycznego powtarzania pewnych czynności. Optymalizacja procesów życiowych wiąże się też z licznymi wyrzeczeniami oraz ścisłą kontrolą wielu aspektów życia. Pozostałe techniki mają ograniczenia w postaci działania selektywnego, na bardzo określoną czynność umysłową, a czasem zmniejszania przez to efektywności innego procesu poznawczego.

\section{Informatyczne wzmocnienie poznawcze}

Ostatnim wymienianym rodzajem wzmocnienia poznawczego są technologie związane z szeroko pojętą informatyką. W przypadku wzmocnienia farmakologicznego środki wpływały bezpośrednio na biochemię mózgu, natomiast wzmocnienie niefarmakologiczne oddziaływało poprzez naturalną stymulację, głównie na proces plastyczności mózgu. Z kolei wzmocnienie informatyczne dotyczy technologii informatycznych, zwłaszcza tych mobilnych i zminiaturyzowanych, które z racji tego, że są blisko ciała, pozwalają na zwiększenie i rozszerzenie funkcji ludzkich, w tym procesów poznawczych. Wzmocnienie $\mathrm{w}$ tym kontekście należy powiązać z koncepcją „poznania rozszerzonego" zaproponowaną przez Andiego Clarka i Davida Chalmersa (1998), wedle 
której procesy poznawcze nie ograniczają się do procesów zachodzących w umyśle i ciele, ale mogą być rozszerzane na zewnętrzne narzędzia, pełniące funkcję przedłużeń umysłu, które przy tym wykazują cechy typowe dla ludzkich umysłów Wykorzystując technologię informatyczną, należy traktować ją jak zewnętrzne przedłużenie umysłu.

Technologie informatyczne z reguły są nieinwazyjne. Samo ich powstanie wiązało się z oddelegowaniem pewnych funkcji umysłowych na maszyny. Komputery pełnią rolę zewnętrznych rozszerzeń pamięci ludzkiej poprzez składowanie danych. Są także rozszerzeniem funkcji wykonawczych dzięki umiejętności rozwiązywania zadań obliczeniowych, które to na dodatek wykonują znacznie szybciej. Ten rodzaj wspomagania oraz integracja/interakcja człowiek-komputer wskazują na zewnętrzność i „narzędziowość”, a wzmocnienie zdolności jest podobne jak w stosunku do książki czy papieru. Rozwój oprogramowania oraz sprzętu (a zwłaszcza miniaturyzacja tego drugiego) nadał technologiom informatycznym znacznie większe możliwości oddziaływania na człowieka i jego władze poznawcze. Zmienił się charakter technologii. Stały się one immersyjne. Oznacza to, że człowiek wchodzi w symbiozę z technologią, która staje się integralną całością ludzkiego ciała. Tak się z nią utożsamia, że staje się ona dla niego wręcz nieodłączna. Dzieje się tak, gdyż umysł adaptuje w przestrzeń swojego bytu dane rozwiązania (narzędzie i/lub technologię), które wzbogacają jego obraz i schemat własnego ciała.

Technologie informacyjne są głównie magazynami pamięci, jednak poprzez funkcje kondensacyjne i agregacyjne na zbiorach danych możliwe jest wspomożenie wrażenia, spostrzegania, myślenia czy percepcji. Szczególnymi narzędziami są systemy data mining ${ }^{30}$ wraz z wizualizacjami, które są abstraktem olbrzymiej ilości danych i możliwe są do szybkiego przetworzenia i adaptacji przez ludzki mózg (Kisielnicki 2008). Systemy takie są rozszerzane o wspomaganie procesów rozumowania, wyobrażania i podejmowania decyzji, na przykład systemy ekspertowe, które zawierają wyspecjalizowaną wiedzę (w bazach wiedzy) i udzielają porad w oparciu o proces analizy i rachun$\mathrm{ku}$ reguł logicznych będący zbliżonym do ludzkiego rozumowania (Stefanowicz 2003), systemy wspomagania decyzji oparte również na bazach wiedzy, które w wyniku wnioskowań podejmują funkcje wykonawcze za człowieka, czy też systemy agentowe, które wykonują określone funkcje wymagające inteligencji w zastępstwie człowieka (Kisielnicki 2008; Wooldridge 2009). W powyższych przypadkach mamy do czynienia z systemami sztucznej inteligencji, a więc systemami symulującymi wybrane funkcje umysłu. Techniki te w sposób „narzędziowy” i pośredni wspomagają ludzkie procesy poznawcze właśnie poprzez oddelegowanie pewnych operacji umysłowych na komputer.

\footnotetext{
${ }^{30}$ Data Mining (eksploracja danych) to jeden z etapów procesu odkrywania wiedzy z baz danych. Idea eksploracji danych polega na wykorzystaniu szybkości komputera do znajdowania ukrytych dla człowieka prawidłowości w danych.
} 
Dzieje się to na zewnątrz ludzkiego ciała, człowiek nie ma więc do tych operacji wglądu ani do tego jak przebiega proces rozumowy, nie jest jego świadomy, a także jego stosunek emocjonalny do danego procesu jest obojętny.

Aktywne wpływanie technologii na ludzkie procesy poznawcze oraz liczne funkcje życiowe w ogóle związane są ze zjawiskami cyborgizacji i immersyjności. Termin cyborg powstał dla określania hipotetycznych organizmów, w których narządy i układy zostały zastąpione układami cybernetycznymi. Postęp technologiczny sprawia, że zjawiska opisywane w powieściach fikcji naukowej stają się faktem. Nie inaczej jest w przypadku cyborgów. Sami jawimy się jako osoby, na które technologia wywiera ogromny wpływ już od pierwszych godzin życia. Proces cyborgizacji dotyczy zarówno ciała, jak i szeroko rozumianych procesów mentalnych, w tym procesów poznawczych. Integracja człowieka $z$ technologią nie polega wyłącznie na fizycznym i inwazyjnym połączeniu. Sama technologia staje się ucieleśniona (co oznacza, że elementy technologiczne biorą udział w procesach poznawczych człowieka), a człowiek wtapia się w przestrzeń technologii (Gunia 2015). Tłumaczy to zjawisko immersji, które w kontekście rzeczywistości wirtualnej oznacza stan świadomości, w której fizyczna jaźń osoby jest zmniejszona lub wchłonięta przez otaczające daną osobę sztuczne środowisko.

Zjawiska immersji i cyborgizacji należy powiązać z technologią zminiaturyzowaną, mobilną, która ściśle jest powiązana z rozwojem globalnej sieci Internet oraz sieciami komórkowymi. Postęp w tej materii sprawił, że technologie stały się bliższe człowiekowi. Oprócz możliwości komunikacji z każdego miejsca na Ziemi, liczne aplikacje na urządzenia mobilne aktywnie i bezpośrednio wspomagają procesy poznawcze. Należy zwłaszcza podkreślić znaczenie technologii rzeczywistości rozszerzonej (ang. augmented reality), która jest subtelnym przenikaniem się bytów realnych z bytami wirtualnymi. System ten łączy świat rzeczywisty $\mathrm{z}$ generowanym komputerowo. Zazwyczaj wykorzystuje się obraz z kamery, na który nałożona jest generowana w czasie rzeczywistym grafika trójwymiarowa. Aktualnie technologia ta dostępna jest na telefony komórkowe, coraz częściej wykorzystuje się specjalne okulary rzeczywistości poszerzonej, w przyszłości w tę technologię miałyby być wyposażone soczewki kontaktowe (Azuma 1997; Kipper i Rampolla 2012). Systemy te w znaczący sposób wzbogacają percepcję wzrokową, a także usprawniają procesy myślowe. $Z$ jeszcze większą przemianą percepcji do czynienia mamy w przypadku rzeczywistości wirtualnej (ang. virtual reality) definiowanej jako środowisko obsługiwane przez użytkownika oraz wchodzące $\mathrm{w}$ nim $\mathrm{w}$ interakcję w czasie rzeczywistym, w którym obraz i inne doznania sensoryczne w całości wygenerowane są za pomocą komputera (Pratt i in. 1995). Wzmocnienie, rozszerzenie czy wręcz przekroczenie dotychczasowego procesu myślenia oraz komunikowania mają umożliwić interfejsy mózg-komputer (ang. braincomputer interface, $B C I$ ). Systemy $B C I$ pozwalają na bezpośrednią komunikację z odpowiednim urządzeniem zewnętrznym w oparciu o aktywność neuro- 
nalną mózgu. Implementacja $B C I$ może być nieinwazyjna w oparciu o odczyt zapisu elektroencefalogramu ( $E E G)$ lub też inwazyjna poprzez podpięcie elektrod w korę mózgu (Vallabhaneni i in. 2005). Sygnały pochodzące z mózgu przetwarzane są na sygnał cyfrowy, co może posłużyć do sterowania komputerem bądź elementami robotycznymi. Te dodatkowo mogą wysyłać z powrotem sygnał do mózgu, który może być interpretowany jako doznanie zmysłowe, na przykład dotyk - pozwalają na to nowoczesne protezy (Raspopovic i in. 2014). Podłączanie implantów nawiązujących do BCI daje możliwość doznawania nowych bodźców zmysłowych, na przykład sensory przetwarzające wrażenia koloru na sygnały dźwiękowe czy wykorzystanie specjalnych sensorów do interpretowania fal (na przykład sieci bezprzewodowych Wi-Fi) niedostępnych dla ludzkich zmysłów na inne sygnały, na przykład na sygnał dźwiękowy (Harbisson 2012). Procesy te oprócz możliwości wzmocnienia poznawczego i sensorycznego poprzez implantację do ciała technologii silnie charakteryzuje proces cyborgizacji.

Warto na koniec wspomnieć jeszcze o jednej metodzie - przezczaszkowej stymulacji magnetycznej (ang. transcranial magnetic stimulation, TMS). Metoda łączy w sobie metody biotechnologiczne, niefarmakologiczne oraz informatyczne. TMS działa w sposób nieinwazyjny, krótkotrwały i całkowicie odwracalny, wpływając na pracę mózgu poprzez depolaryzację i hiperpolaryzację neuronów. Oprócz korzyści terapeutycznych, takich jak wyciąganie z depresji czy efekty w zwalczaniu uzależnień, stymulacja poszerza mózgową plastyczność, co sprzyja pobudzeniu w czasie proceduralnej nauki, wzmacnianiu pamięci roboczej czy wpływaniu pozytywnie na funkcje motoryczne (Barker i in. 1985).

Wzmocnienie informatyczne nie tylko wspomaga procesy poznawcze, ale też silnie oddziałuje na ludzką cielesność. Wzmocnienie informatyczne przyczynia się do zmiany odbierania obrazu i schematu ciała u osób korzystających z tych rozwiązań. Adaptowana technologia wpływa na stany emocjonalne, co sprawia, że traktuje się technologiczne wzmocnienie jako nierozerwalną część siebie. Wzmocnienie poznawcze $\mathrm{w}$ kontekście informatycznym nadaje procesom poznawczym nową jakość, szczególnie odnosi się to do technologicznych sensorów, które odbierają bodźce niedostępne bądź słabo dostępne ludzkim zmysłom. Symbioza ${ }^{31}$ człowieka $\mathrm{z}$ technologią mogącą składować i przetwarzać ogromne ilości informacji otwiera przed nim nowe możliwości - gdy człowiek będzie miał na bieżąco dostęp do wiedzy, kwestie poznawcze takie jak uczenie (i tradycyjne podejście do edukacji takie jak zapamiętywanie informacji) przestaną odgrywać kluczową rolę; ważny będzie kontekst, sposób

\footnotetext{
${ }^{31}$ Rozumiana jako ścisłe oddziaływanie technologii na człowieka. W przypadku implantacji, technologia staje się częścią jego cielesności. Zarówno przy oddziaływaniu bez implantacji, jak i w przypadku implantacji utrata powiązania z technologią skutkuje znaczącym pogorszeniem jakości życia.
} 
wyszukiwania, aktualność danych oraz możliwe zastosowanie tej wiedzy. Oprócz optymistycznych i pozytywnych aspektów wzmocnienia poznawczego pojawia się także druga strona medalu. Jeśli technologia będzie mogła wyręczyć ludzi w tak wielu aspektach życia, to czy człowiek nie zostanie przez nią wyparty? Ponadto jeśli niektóre procesy poznawcze takie jak uczenie przestaną być istotne, to czy człowiek nie rozleniwi się tak, że wzmocnienie nie będzie miało znaczenia? A także czy technologia nie będzie narzędziem ucisku? Jeśli jest zaprogramowana, by pomóc człowiekowi, to nie widać żadnych przeciwwskazań. Jednak równie łatwo daje się ona zaprogramować w sposób nieprzynoszący ludziom korzyści. Gdy technologia będzie blisko umysłu, wpływając na niego, to czy zhakowanie technologii nie będzie równoznaczne z manipulacją umysłu? Mimo znaczących korzyści ważne jest, by człowiek potrafił odróżnić elementy naturalnej efektywności od siły działania wzmocnienia wynikającej z zastosowania technologii informatycznych.

\section{Wyzwania i wątpliwości. Podsumowanie}

Tematyka wzmocnienia poznawczego w kontekście akademickim jest stosunkowo nowa i od samego początku budzi wiele pytań natury etycznej. Zaznacza się, że dzięki wykorzystaniu wielu technik i metod, można w znaczący sposób usprawnić ludzkie poznanie. Wzmocnienie poznawcze to obecnie nie tylko teorie transhumanistów i futurologów, to także liczne interdyscyplinarne projekty w wielu miejscach na świecie. Na gruncie polskiej nauki tematyka wzmocnienia poznawczego nie znajduje jednak wielu entuzjastów zarówno od strony teoretycznej, jak i praktycznej. Wzmocnienie jest głównie analizowane $\mathrm{w}$ kontekście terapeutycznym, ma redukować zaburzenia, bądź też przywracać funkcjonalność procesów poznawczych utraconą w wyniku zaburzeń chorobowych ${ }^{32}$, prowadzone są też badania nad wpływem technologii na kreatywność (Duch, 2006). Inne aspekty w niewielkim stopniu są badane.

Mimo iż wydawać się może, że część metod wzmocnienia poznawczego jest dobrze znana i udokumentowana, to nowatorskość tego podejścia należy upatrywać przede wszystkim w:

a) aktywnym wykorzystaniu zaawansowanych technologii, które nie tylko pełnią funkcję narzędzi, lecz stają się elementem ludzkiej cielesności bądź umysłowości;

b) sposobach określania wpływu, siły lub oceny skuteczności działania metod, a w związku z tym wypracowaniem adekwatnych miar;

c) interdyscyplinarnym podejściu do kwestii poznawczych oraz na zbieżnym (równoczesnym) wykorzystaniu wielu metod, technik i narzędzi.

32 Zob. Typoszereg komputerowych interfejsów multimodalnych (dostęp online: http://sound.eti.pg.gda.pl/ kosiq/typo/projekt.php). 
Aktualnie pojawia się dosyć poważny problem związany z ewaluacją skuteczności tych metod. Wynika to $\mathrm{z}$ trudności mierzenia ilościowego, a także jakościowego, efektywności procesów poznawczych. Najpowszechniejszą miarą postępów jednostki w rozwoju intelektualnym jest iloraz inteligencji. Na jego podstawie można wysnuć wniosek, że elementy wzmocnienia są efektywne, czego dowodzi efekt Flynna, według którego wzrost ilorazu inteligencji w krajach cywilizacji zachodniej wzrasta o 2,5 punktu na każdą dekadę $(1987)^{33}$. Innymi możliwymi do zastosowania syntetycznymi miarami są mierzenie efektywności pracy, wzrost dobrobytu, lepsze wyniki w sporcie itp. Niemniej wyzwaniem jest utworzenie nowych wskaźników dla mierzenia procesów mentalnych.

Innym zasadniczym problemem związanym z wzmocnieniem poznawczym są szeroko pojęte kwestie etyczne, moralne, społeczne, a także polityczne. Kwestie te wiążą się z obawą co do ingerencji $\mathrm{w}$ tak subtelny obszar jak ludzkie władze poznawcze. Wątpliwości dotyczą przede wszystkim tego, czy elementy wzmocnienia nie będą prowadzić do dehumanizacji na przykład poprzez eliminację niektórych potencjalnie niepotrzebnych emocji, które dotychczas nadawały sens ludzkiej egzystencji. Wzmacniać i usprawniać jak najbardziej należy, jednak debata w tej kwestii jest niezbędna. Przeprogramowanie ludzkiej świadomości w taki sposób, że nie będzie się w stanie odczuwać bólu, kierować popędami i emocjami, za to zostanie wstawiona niezwykle pojemna pamięć z niezwykłą mocą obliczeniową jest scenariuszem wielce prawdopodobnym. Zachować należy zdrowy rozsądek. Mimo że pewne stany mentalne osłabiają na przykład inteligencję, nie powinno się ich za wszelką cenę redukować. Również pojawia się pytanie o dostępność środków: czy będą one dostępne dla każdego, czy tylko dla wybranych? A także: czy nie staną się narzędziem do manipulacji i nadużyć? Granica między wzmocnieniem a zniszczeniem jest więc bardzo cienka. Dlatego wraz z powstającymi technologiami niezbędne są liczne debaty filozoficzne, socjologiczne i psychologiczne wokół tematyki biopolityki oraz dehumanizacji. Postęp technologiczny dokonuje się $\mathrm{w}$ błyskawicznym tempie, dlatego tak istotne jest, by z debatami filozoficznospołecznymi się nie spóźnić.

\section{Literatura}

Azuma, R.T. 1997. A survey of augmented reality. Presence, 6(4): 355-385.

Barker, A.T., Jalinous, R. i Freeston, I.L. 1985. Non-invasive magnetic stimulation of human motor cortex. The Lancet, 325(8437): 1106-1107.

Bostrom, N. i Sandberg, A. 2009. Cognitive enhancement: Methods, ethics, regulatory challenges. Science and Engineering Ethics. 15(3): 311-341.

\footnotetext{
${ }^{33}$ Stąd też testy na inteligencję są korygowane tak, by przeciętna wartość zawsze była na poziomie 100 .
} 
Bostrom, N. i Savulescu, J. 2009. Human enhancement ethics: the state of the debate. J. Savulescu i N. Bostrom, red. Human enhancement: 1-24. Oxford: University Press.

Bostrom, N. 2005. Transhumanist values. Review of Contemporary Philosophy, 4(1-2): 87-101.

Brukamp, K. 2013. Better brains or bitter brains? The ethics of neuroenhancement. E. Hildt i A.G. Franke, red. Cognitive Enhancement. An Interdisciplinary Perspective: 99-112. Springer Netherlands.

Bublitz, J.C. 2013. My mind is mine!? Cognitive liberty as a legal concept. E. Hildt i A.G. Franke, red. Cognitive Enhancement. An Interdisciplinary Perspective: 233-264. Springer Netherlands.

Clark, A. i Chalmers, D. 1998. The extended mind. Analysis, 58(1): 7-19.

Clark, A. 2004. Natural-born cyborgs: Minds, technologies, and the future of human intelligence. Oxford: University Press.

DeGrazia, D. 2000. Prozac, Enhancement, and Self-Creation. Hastings Center Report, 30(2): 34-40.

Dialogue between Ray Kurzweil and Eric Drexler. 2013. M. More i N. Vita-More, red. The Transhumanist Reader: Classical and Contemporary Essays on the Science, Technology, and Philosophy of the Human Future: 205-211. John Wiley \& Sons.

Dresler M. i in. 2013. Non-pharmacological cognitive enhancement. Neuropharmacology, 64: 529-543.

Duch, W. 2006. Computational creativity. Neural Networks, IJCNN'06: 435-442.

Edelman, G. i Tononi, M.G. 2000. A universe of consciousness: How matter becomes imagination. New York: Basic books.

Fischer, K. 2012. Human Cognitive Enhancement Interventions. Źródło: https://www.youtube.com/watch?v=qvpRjvAuXD0 , 19.11.2015.

Flynn, J.R. 1987. Massive IQ gains in 14 nations: What IQ tests really measure. Psychological bulletin, 101(2): 171.

Forsberg, L. 2013. No Pain, No Gain? Objections to the Use of Cognitive Enhancement on the Basis of Its Potential Effects on the Value of Achievement. E. Hildt i A.G. Franke, red. Cognitive Enhancement. An Interdisciplinary Perspective: 159-171. Springer Netherlands.

Franke, A.G. i Lieb, K. 2013. Pharmacological Neuroenhancement: Substances and Epidemiology. E. Hildt i A.G. Franke, red. Cognitive Enhancement. An Interdisciplinary Perspective: 17-27. Springer Netherlands.

Gilbert, F. 2013. Nano-bionic Devices for the Purpose of Cognitive Enhancement: Toward a Preliminary Ethical Framework. E. Hildt i A.G. Franke, red. Cognitive Enhancement. An Interdisciplinary Perspective: 125-138. Springer Netherlands.

Gunia, A. 2015. Dlaczego stajemy się cyborgami - problem adaptacyjności umysłu i ciała do wytworów technologii. M. Jakubiak i M. Kaszubowska, red. Umyst i Poznanie: 101-111. Szczecin: Volumina. 
Harbisson, N. 2012. I listen to color. Źródło: https://www.ted.com/talks/neil_harbisson _i_listen_to_color, 28.11.2015.

Hauskeller, M. 2013. Cognitive Enhancement - To What End? E. Hildt i A.G. Franke, red. Cognitive Enhancement. An Interdisciplinary Perspective: 113-123. Springer Netherlands.

Hildt, E. 2013. Cognitive enhancement-A critical look at the recent debate, w: Cognitive Enhancement. An Interdisciplinary Perspective. E. Hildt i A.G. Franke, red. Cognitive Enhancement. An Interdisciplinary Perspective: 1-14. Springer Netherlands.

Horn, R.E. 2002. Beginning to conceptualize the human cognome project. Źródło: http://www.stanford.edu/ rhorn/ArtclCognome.html , 27.11.2015.

Juengst, E.T. 1998. What does enhancement mean. Enhancing human traits: Ethical and social implications. E. Parens, red. Enhancing human traits: Ethical and social implications: 29-47. Georgetown: University Press.

Kipke, R. 2013. What Is Cognitive Enhancement and Is It Justified to Point Out This Kind of Enhancement Within the Ethical Discussion? E. Hildt i A.G. Franke, red. Cognitive Enhancement. An Interdisciplinary Perspective: 145-157. Springer Netherlands.

Kipper, G. i Rampolla, J. 2012. Augmented Reality: an emerging technologies guide to AR. Waltham: Elsevier.

Kisielnicki, J. 2008. MIS - Systemy Informatyczne Zarządzania. Warszawa: Placet.

Lanni, C., i in. 2008. Cognition enhancers between treating and doping the mind. Pharmacological Research, 57(3): 196-213.

More, M. 2013. A letter to Mother Nature M. More i N. Vita-More, red. The Transhumanist Reader: Classical and Contemporary Essays on the Science, Technology, and Philosophy of the Human Future: 449-450. John Wiley \& Sons.

Pearce, D. 2004. Hedonistic Imperative. Źródło: https://cl.nfshost.com/david-pearce-thehedonistic-imperative.pdf, 27.11.2015.

Pearce, D. 2007. The abolitionist project. Źródło: http://www.abolitionist.com/ , 27.11.2015.

Pearce, D. 2009. The Reproductive Revolution Selection Pressure in a Post-Darwinian World. Źródło: http://www.reproductive-revolution.com/index.html , 27.11.2015.

Pearce, D. 2014. The good drug guide. Źródło: http://www.biopsychiatry.com/ , 27.11.2015.

Pranav, J.C. 2013. A Review on Natural Memory Enhancers (Nootropics). Unique Journal of Engineering and Advanced Sciences, 1(1): 8-18.

Pratt, D.R., Zyda, M., i Kelleher, K. 1995. Virtual reality: In the mind of the beholder. Computer, 28(7): 17-19.

Racine E. i Forlini, C. 2010. Cognitive enhancement, lifestyle choice or misuse of prescription drugs? Neuroethics, 3(1): 1-4. 
Raspopovic, S., Capogrosso, M. i in. 2014. Restoring natural sensory feedback in realtime bidirectional hand prostheses. Science translational medicine, 6(222): 1-10.

Roco, M.C. i Bainbridge, W.S. 2003. Converging technologies for improving human performance: Nanotechnology, biotechnology, information technology and cognitive science. Dordrecht: Kluwer Academic Publishers.

Sandberg, A. i Bostrom, N. 2006. Converging cognitive enhancements. Annals of the New York Academy of Sciences, 1093(1): 201-227.

Schneider, J.S. i in. 2001. Enriched environment during development is protective against lead-induced neurotoxicity. Brain research, 896(1): 48-55.

Smith, P. J. i in. 2010. Aerobic exercise and neurocognitive performance: a metaanalytic review of randomized controlled trials. Psychosomatic medicine, 72(3): 239252.

Soetens, E., D'Hooge, R. i Hueting, J. E. 1993. Amphetamine enhances human-memory consolidation. Neuroscience letters, 161(1): 9-12.

Stefanowicz, B. 2003. Systemy eksperckie: przewodnik. Warszawa: Wyższa Szkoła Informatyki Stosowanej i Zarządzania.

Turner, D. C. i in. 2003. Cognitive enhancing effects of modafinil in healthy volunteers. Psychopharmacology, 165(3): 260-269.

Typoszereg komputerowych interfejsów multimodalnych. Źródło: http://sound.eti.pg.gda.pl/ kosiq/typo/projekt.php, 21.12.2015.

Vallabhaneni, A., Wang, T., i He, B. 2005. Brain-computer interface. B. He, red. Neural engineering: 85-121. Springer US.

Wilińska, K. 2013. Pojęcie i znaczenie treningu mentalnego w aktywności sportowej. Źródło: $\quad$ http://www.azstenis.pl/publikacje/item/804-poj\%C4\%99cie-i-znaczenietreningu-mentalnego-w-aktywno\%C5\%9Bci-sportowej.html , 20.11.2015.

Winship, C. i Korenman, S. 1997. Does staying in school make you smarter? The effect of education on IQ in The Bell Curve. B. Devlin, red. Intelligence, genes, and success: Scientists respond to The Bell Curve: 215-234. New York: Springer.

Wooldridge, M. 2009. An introduction to multiagent systems. John Wiley \& Sons. 


\section{Cognitive enhancement. Effort of definition, and methods}

Abstract: The idea of cognitive enhancement refers to multifaceted and interdisciplinary approach aimed at improving human mental processes. Cognitive enhancement is the amplification or extension of core mind capacities through improvement or augmentation of either internal or external information processing systems. This includes improvements of intelligence and attention, reinforcement of creativity and memory, or extension of perception range. The main feature of cognitive enhancement is voluntariness of use for overcoming natural mental limitations. This article is a synthesis of current trends in cognitive enhancement from the perspective of transhumanism. The article presents various definitions of cognitive enhancement, methods of cognitive enhancement (biotechnological methods, non-pharmacological methods, IT methods) as well as challenges and questions concerning improving human mental processes.

Keywords: cognition; cognitive enhancement; human enhancement; cognitive science; transhumanism. 